Meta

Journal des traducteurs

Translators' Journal

\title{
Punctuation in English \& Portuguese Translations: When Every Point Counts
}

\section{Cecil L. de Ataide Melo}

Volume 35, numéro 4, décembre 1990

URI : https://id.erudit.org/iderudit/003625ar

DOI : https://doi.org/10.7202/003625ar

Aller au sommaire du numéro

Éditeur(s)

Les Presses de l'Université de Montréal

ISSN

0026-0452 (imprimé)

1492-1421 (numérique)

Découvrir la revue

Citer cet article

de Ataide Melo, C. L. (1990). Punctuation in English \& Portuguese Translations: When Every Point Counts. Meta, 35(4), 720-731.

https://doi.org/10.7202/003625ar
Résumé de l'article

This is an investigate study on the frequency of punctuation use in Brazilian Portuguese and American English translations. Six textual pairs were selected, each representing a particular genre of translation. Punctuation was divided into two contrasting categories. Under terminal punctuation were placed marks which came at the end of sentences and caused the next word to be capitalized. Under internal punctuation were included marks which appeared within the sentence limits. 1692 marks in 622 sentences were carefully tabulated and constituted the corpus of this project. Results indicated that Portuguese texts were considerably more populated by various punctuation marks than their English counterparts. Frequent rhetorical pauses, tolerance towards longer and more complex sentences, and occasional use of double punctuation invited a higher ratio of marks per sentece in the Portuguese texts. In the last part of the paper, a number of conventions governing punctuation usage in the two languages are discussed, providing a direct application to the training of translators and students of foreign language composition and rhetoric. 


\title{
PUNCTUATION IN ENGLISH \& PORTUGUESE TRANSLATIONS: WHEN EVERY POINT COUNTS
}

CECIL L. DE ATAIDE MELO

University of South Carolina, Columbia, S.C., USA

\begin{abstract}
This is an investigate study on the frequency of punctuation use in Brazilian Portuguese and American English translations. Six textual pairs were selected, each representing a particular genre of translation. Punctuation was divided into two contrasting categories. Under terminal punctuation were placed marks which came at the end of sentences and caused the next word to be capitalized. Under internal punctuation were included marks which appeared within the sentence limits. 1692 marks in 622 sentences were carefully tabulated and constituted the corpus of this project. Results indicated that Portuguese texts were considerably more populated by various punctuation marks than their English counterparts. Frequent rhetorical pauses, tolerance towards longer and more complex sentences, and occasional use of double punctuation invited a higher ratio of marks per sentece in the Portuguese texts. In the last part of the paper, a number of conventions governing punctuation usage in the two languages are discussed, providing a direct application to the training of translators and students of foreign language composition and rhetoric.
\end{abstract}

\section{INTRODUCTION}

It is an intriguing question for language researchers: What happens to the punctuation of a text when it is translated? The answer to this largely unexamined aspect of translation is only now emerging in the literature.

Traditionally, punctuation has been treated in previously proposed translation theories as a separate entity in the source and target language, without any major attempt to integrate contrastive punctuation as an observable, and possibly measurable, component of various translation theories. An yet, punctuation is one of the most visible elements to be affected in translation, particularly in translations which aim at a level of dynamic equivalence as proposed by Nida (1964) and Nida \& Taber (1969).

If for the practitioner the classic approach to describing punctuation in terms of rules and exceptions in each language presents limitations (Spilka 1983), for the novice translator or advanced language student this individualized treatment of punctuation sheds no light on the way punctuation is actually used in translation. While comparative studies dealing with American English and Brazilian Portuguese ${ }^{1}$ punctuation are unavailable in the literature, other language pairs have attracted more attention and enjoyed more prominence. This is the case for French and English in the works of Spilka (1983; 1985), and English and other germanic languages in Nichols (1962).

My goal in this paper is (1) to address the development and current trends of punctuation, (2) to present the results of a punctuation count of 1692 marks, and (3) to contrast established punctuation usage between English and Portuguese as a practical application to the training of translators and advanced language students. The paper is the product of observing the use of punctuation in six contrasting styles of currently published translations. All findings are derived and quantified from such a corpus. 


\section{HISTORICAL DEVELOPMENTS}

In its earliest form, punctuation was mostly used in English to indicate pauses between sentences, thus enabling the reader to anticipate where to stop or raise the voice (Fowler \& Fowler, 1931: 230). But indicating pauses is only one of the functions of punctuation as we know it today. Modern punctuation, with its inventory of a dozen symbols, is two-fold. It is used to indicate breath pauses and to mark grammatical boundaries and relations within the sentence. As a result, we are left today with two traditions regulating the use of punctuation marks: 1) the rhetorical tradition and 2) the grammatical tradition (Little 1984a).

Pedagogically, the grammatical tradition of punctuation has outlived the rhetorical bases of punctuation and has found its way into our contemporary manuals of style, grammar books, and dictionaries. For one, it is seen as a more manageable approach to the teaching of punctuation. It attempts to reduce the subjectivity of the rhetorical approach by using the various marks to clarify grammatical structures. Thus, to say that "commas are commonly used to set off non-restrictive clauses" provides a handle for students and facilitates the teaching of punctuation in the classroom.

In practice however punctuation is inseparable from the writing process, cultivated in style, and less mechanical an activity than it may first appear (Summey 1949). It is recognized that modern punctuation incorporates both traditions to enhance and modify sentence meaning rather than to place straitjackets on professional writers and translators. Little (1984a) rightly maintains that "it is foolish to attempt to separate the grammatical and rhetorical foundations for punctuation," and argues that "punctuation that is governed solely by grammatical structure is redundant and adds nothing to the meaning sentence."; As we look at punctuation in a cross linguistic context, the two traditions continue to enjoy a productive and symbiotic existence in both English and Portuguese in the 1980's.

\section{CURRENT DEVELOPMENTS}

The economic use of punctuation in English, particularly internal punctuation marks such as commas and dashes, has been commonly regarded as one of the typical features of the language. George Summey, in his pioneering studies of American punctwation, demonstrated that the trend toward light punctuation - the use of punctuation marks as sparsely as possible - has been gaining more and more terrain in contemporary American English. Summey (1919) counts 20,000 punctuation marks in books, magazines, and newspapers and sets the stage for his next ambitious project. Thirty years later, Summey performs a second count on the basis of the same methodology proposed in 1919. In American Punctuation (1949: 157), Summey demonstrates that "heavy punctuation in a thing of the past," and concludes that "sentence structure has noticeably lightened in the past three decades." Would Summey's findings still hold true forty years later? Unfortunately, follow-up studies taking into consideration a much larger corpus have been unavailable since then.

In Portuguese, the paucity of methodological studies on punctuation use has been a serious hindrance in quantifying changes and comparing its frequency with other languages. The traditional approach to punctuation remains largely prescriptive and pedagogically oriented. Invariably, this has been the traditional treatment of Portuguese punctuation in the works of Passos (1959), Melo (1966), and Olívia (1982). An effort is made by the renown Brazilian linguist Joaquim Mattoso Câmara to discuss punctuation within a linguistic framework. In Mattoso Câmara (1977: 36), punctuation is approached in terms of its prosodic features, with periods, commas, colons, and semicolons being classified according to gradations of breath pauses which these marks supposedly convey to the reader. Largely impressionistic in nature, Mattoso Câmara's discussion unfortunately has left punctuation as a whole virtually untouched. 
The frequency in the use of punctuation in the two languages nevertheless shows very distinct patterns, as we will later see in this study. While Portuguese seems to use rhetorical-based punctuation to the fullest, English is more frugal in its use of commas, dashes, and colons to impart rhetorical boundaries. The rhetorical function of Portuguese punctuation is captured in (1) and (2) (Notice that brackets will be consistently used throughout this work to highlight various punctuation environments):

(1) Portugueses instituiram as brincadeiras de rua e [,] hoje[,] aliado a essa animação[,] surge o tema Constituinte no Carnaval. (Folha de São Paulo, February 5, 1987: B-19)

(2) Recife ressucita[,] a cada ano[,] uma das mais tradicionais manifestaçöes populares de Pernambuco... (Folha de São Paulo, February 5, 1987: B-18)

It is important to bear in mind that English also employs punctuation for rhetorical or elocutionary reasons. However, when we compare the frequency of rhetorically based punctuation in the two languages, we see opposite patterns. Rhetorical punctuation in English is more sporadic, discourages by authority, and less conspicuous compared to that of Portuguese. It is interesting to notice in the corpus the frequency with which rhetorically marked pauses in the Portuguese Source Texts (ST) are eliminated when translated into English and vice-versa. But just how frequent is the use of rhetorical punctuation in the two languages? Take the absence of punctuation to set off transitional expressions (therefore, however, hence, etc.) as in (3), and to signal introductory clauses as in (4) below. (By convention, Source Texts (ST) will appear in the first column from left to right. Target Texts (TT) will be placed in the second column. See Bibliography for further bibliographical references.)

(3) O novo Governo tinha plena consciência desse quadro. Por isso[,] ao tempo em que convivia... (p. 1)

The Government that took office this year was fully conginzant of that panorama. Hence[ ] at the same time it had to cope with... (p. 1)

TEXTUAL PAIR: Business

(4) O novo Governo tinha plena consciência desse quadro. Por isso[,] ao tempo em que convivia... (p. 1)
The Government that took office this year was fully conginzant of that panorama. Hence[ ] at the same time it had to cope with... (p. 1)

TEXTUAL PAIR: Journalistic

In English, the environment for rhetorical punctuation is increasingly occurring in print, particularly in magazines and newspapers, without being punctuated. In Portuguese, we observea reverse phenomenon, i.e. little tolerance for leaving rhetorical pauses unpunctuated. Rare are the cases where rhetorical pauses are left unpunctuated in Portuguese texts. Typically, most Brazilians think of rhetorical-based punctuation as markers to indicate proper reading pauses. The commonly heard argument in favor of tightly controlled punctuation goes something like this: "Rhetorical punctuation clarifies meaning and relations within the sentence. Reading may become impaired and affected by ambiguity if pauses are not properly indicated." More often than not, this is the basis on which rhetorical punctuation is justified in (1) and (2), leading to a debate whether the frequent use of rhetorical punctuation helps or spoonfeeds reading. While I do not wish to argue in this paper for either the relevance or irrelevance of overpunctuating. One cannot 
help but wonder if the reading of (1) and (2) would be affected had the rhetorical commas in brackets been removed. For our purposes here, it suffices to point out that rhetorical punctuation in both Portuguese source and target texts plays a greater role than does rhetorical punctuation in their English counterparts. When readers choose to read a translation, they approach it with certain expectations, one of which is to see the same kinds of punctuation boundaries they normally find in their native language. Translations will read less like translations to these readers if punctuation is adequately adjusted to reflect the usueal practices of the target language.

\section{PUNCTUATION COUNT} METHOD

This project is based on a corpus of six contrasting styles of English/Portuguese rextual pairs. The sources were carefully selected so as to reflect current usage in punctuating American English and Brazilian Portuguese. To ensure objectivity and authenticity to the project, the six source texts and their accompanying translations wer all slected from published works.

The choice of textual pairs was made on the basis of author's prominence, editorial standards for accompanying translations, and availability of translated texts at the time the corpus was being compiled. The six different styles of textual pairs were evenly divided between English and Portuguese, with English being the source language for the Technical, Jurnalistic, and Juvenile Literary Textual Pairs, and Portuguese for the Literary, Business, and Lieterary Textual Pairs.

The model used for the count in Table A is slightly modified version of a model for punctuation count proposed by Summey (1949). In the original model, Summey compiled 100 sentences per text in a 2,000 sentence corpus. Suc parameters proved too ambitious for this project and had to be reduced because of the constraints on textual material available. Summey tallied 1,000 per text and counted the occurrence of individual marks of punctuation. In this study, it became evident that simply stopping the count whenever the 1,000th word appeared in the source and target texts proved counterproductive because of frequent disparities in length between the two texts in the pair. Since translations tend to be generally longer than the original, many times this produced a wide gap between the original and the target text. Therefore, it was finally decided that 1,000 words would be the ideal goal for ST and TT length, but the entire paragraph in which the 1,000 th word was found would be maintained as the ultimate cutoff point.

Punctuation in Table A is divided into two contrasting categories. Under "Terminal Punctuation" are marks which come at the end of the sentence and cause the next word to be capitalized. These include periods, question marks, exclamation marks, colons, and ellipses. The second category - "internal punctuation - includes marks which appear within the sentence boundaries and cause no capitalization. Under terminal punctuation in Table A we find commas, dashes, semicolons, parenthesis, colons, exclamation marks, ellipses, and question marks. Notice that [: ! ... ?] are represented in both groups. Since these marks alternate in function, at times appearing as terminal punctuation and at other times as internal marks, they were tabulated accordingly.

Finally, the average number of punctuation marks per sentence was calculated dividing the number of marks each text contained by the total number of sentences.

\section{RESULTS}

The frequency in the use of punctuation marks between Porguese and English texts presents sharp contrasts. My count of 1,692 marks in the six textual pairs reveals that punctuation in Porguguese texts is significantly heavier than in their English counterpart regardless of text style. 


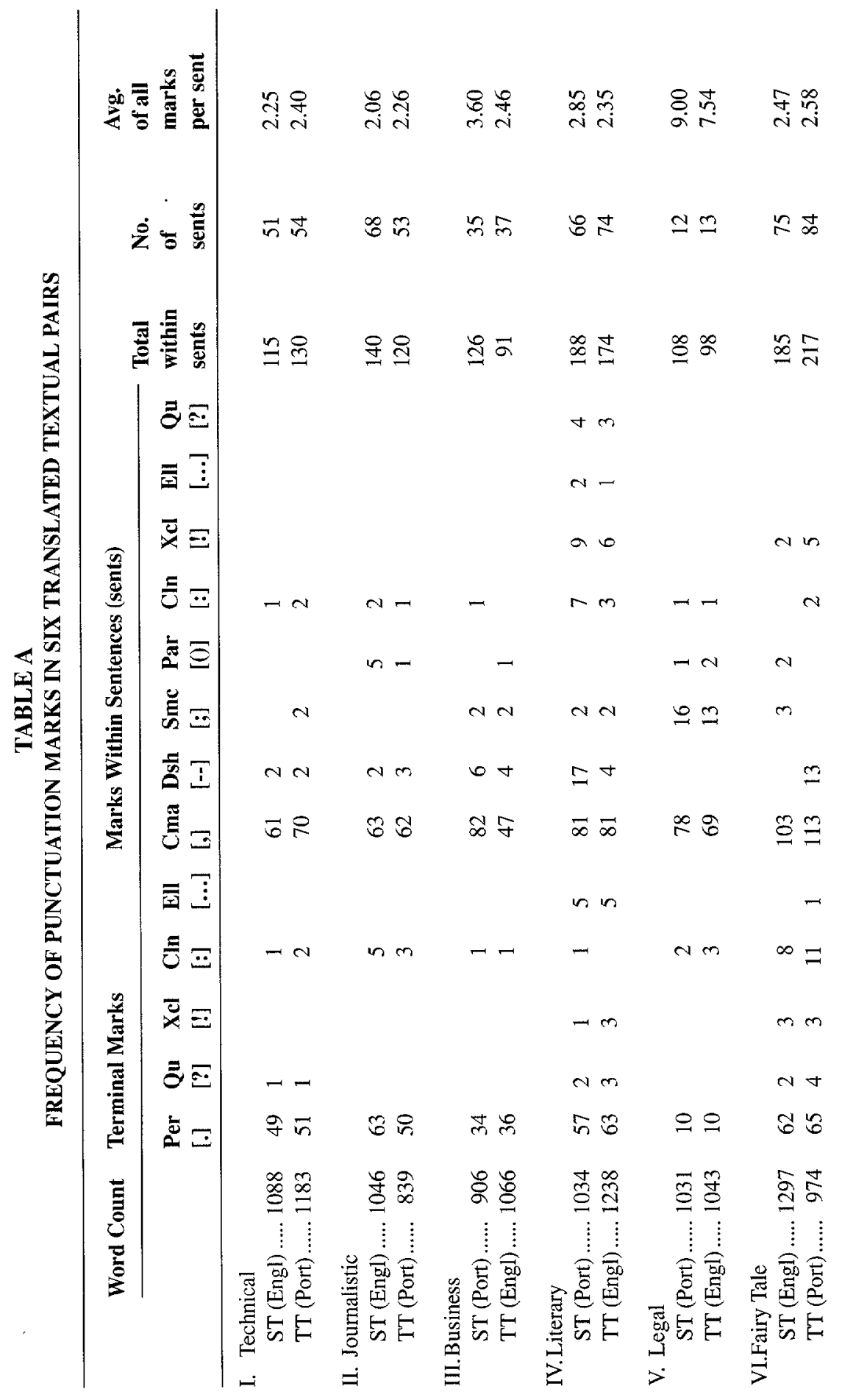




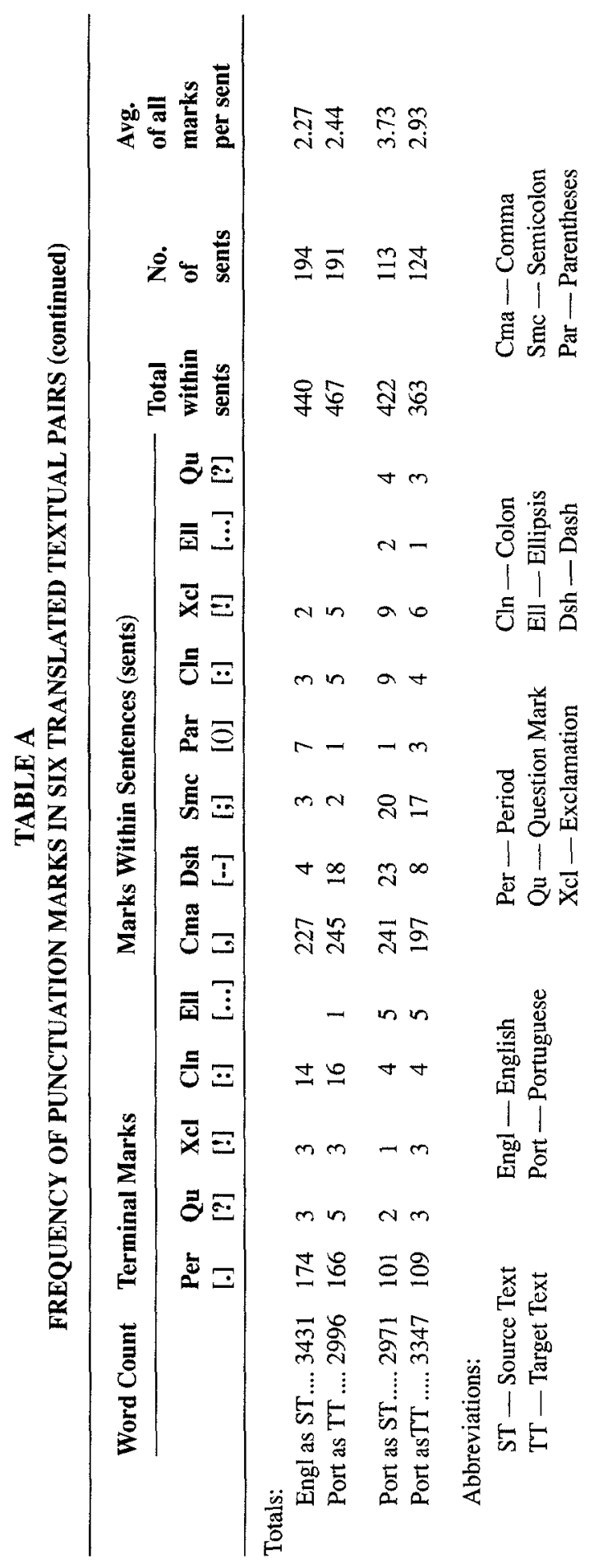


The average punctuation mark per sentence is shown in the last column of Table A. There we find that Portuguese scores higher both as a source language (SL) and a target language (TL). As a SL for half of the corpus, Portuguese scores an average of 3.73 marks per sentence while the respective English translations average 2.93 marks per sentence. Equally high is the number of marks within the sentence, including commas, dashes, semicolons, and colons; 422 marks are counted for the Portuguese ST's as opposed to 363 for the English TT's. The number of sentences signaled by terminal punctuation marks also increased from 113 in the Portuguese STs to 124 in the English TTs. In other words, the increase of these terminal marks in the English translations strngly suggests that a number of complex sentences in the Portuguese STs are split into separate independent clauses as they reemerge in the English TTs. In later contrasting STs and TTs, it was found that in fact terminal punctuation had been used to simplify sentence structure and to accomodate a light style of punctuation as described by Summey (1949).

When Portuguese is the target language for the other half of the corpus, the average of punctuation marks also increases, although not so dramatically. Compare 2.27 marks per sentence in the English STs to 2.44 marks in the respective Portuguese translations of those texts. The number of terminal marks in these translations however remains fairly stabilized.

Some styles are more heavily punctuated than others in the corpus, which accounts for some numerical extremes in Table A. While there is an almost one-to-one correspondence in the number - but not the placement - of commas in the literary textual pair ( 81 commas in both ST and TT), the business textual pair presents a wide difference of usage between ST and TT. As a result, we find 82 occurrences of the comma in the Portuguese ST as compared to an economical use of 47 commas in the English TT. Put another way, half of the commas in the ST are eliminated in the English business TT.

Looking at the period column in Table $\mathrm{A}$, we notice a very low number of periods in the legal textual pair. The small number of periods in the pair mistakenly gives the impression of exceptionally long sentences. Thus the inflated average of 9.00 marks per sentence in the ST and 7.54 for the TT. In reality, what we find in both texts is an abundance of semicolons playing the role of terminal punctuation, setting up long and complex series of items that compose the terms of that legal document. Because of this anomalous use for the semicolon in contrast with the rest of the corpus, I made no provisions to include the semicolon as a terminal mark in this study. In referring to periods and semicolons, it is interesting to note that these two marks never replaced each other in the corpus, despite the fact that Portuguese and English handbooks and manuals of style emphasize a close relationship between the two marks. Instead, what we did find in going from one language to another was periods and colons frequently replacing each other.

Finally the correlation between internal versus terminal punctuation in English and Portuguese TTs raises provocative questions. In the corpus, we are confronted with a situation in which punctuation in English TTs is more affected and undergoes more changes than in Portuguese TTs.

\section{TABLE B}

No. of

Terminal Marks

(A) Port as a SL

Engl as a TT

(B) Engl as a ST

Port as a TT
113

124

194

191
Avg. Marks

per Sentence

3.73

2.93

2.27

2.44 
In Table B, otice that in group (A) the English TTs have undergone greater structural changes where more terminal marks are used to accommodate a lighter style of punctuation. Punctuation adjustment in Group (B), on the other hand, shows fewer signs of structural changes, even though punctuation in Portuguese typically invites a higher ratio of marks per sentence. Why did the composite of Portuguese TTs in (B) closely follow the pattern of light punctuation of the English STs? Judging from the volume of scientific, journalistic, and literary works translated from English into Portuguese, it would be reasonable to claim interlanguage interference via translation in those target texts. Clearly, the characteristic use of light punctuation in English passed unfiltered to the Portuguese TTs in Table B, raising the question of translation quality, particularly in translations aiming to achieve a level of dynamic equivalence. This is an interesting aspect to consider in dealing with translation quality assessment, but for now is outside the scope of this project.

\section{COMPARING PUNCTUATION}

Placing [,] [-] and [" "]

Although Portuguese and English share the same inventory of punctuation marks, the way these marks are ultimately used in each language may vary considerably. Let us now compare English and Portuguese punctuation from the typographical perspective, focusing on accepted norms of usage in the two languages. Commas, dashes, and quotation marks will be aproached from their textual function as they are used to enclose, separate, and highlight textual information.

\section{Enclosing}

In English, commas and other punctuation marks are commonly placed inside closing quotes, regardless of the types of pauses these marks impart. Portuguese usage takes the opposite approach and places all punctuation outside closing quotes.

(5) Marx said: "The history of all society so far is history of class struggle[.]" (p. 92)
Marx pregava: "A História de todas as sociedades, até hoje, é a luta de classes" [.] (p. 138)

TEXTUAL PAIR: Journalistic

It is important to bear in mind that not all varieties of English subscribe to the use of placing punctuation inside closing quotes. British English (BE), for example, does not. In BE punctuation is normally placed outside closing quotes similarly to Portuguese. In addition, BE favors the use of single quotation marks [" '] - "inverted commas" as they are known in Britain - to enclose direct speech, reserving double quotation marks [" "] to enclose a quotation within a quotation. Both practices are exact opposites in the two varieties of English.

Placing sentences within quotation marks signals a shift in the narrative and serves to indicate what someone has said or written in the exact words of the original. These shifts are commonly signaled by concluding or explanatory words such as He said or She asked before, after, or in the middle of the quote, followed by a colon as in (5) or by a comma as in (6) and (7)

(6) "Brazil has some cash problems[,"] said William C. Butcher, chief executive of the chase Manhattan Bank, at a dinner with Washington reporters. (New York Times. February 21, 1987, p. 18.)

(7) "Somos vitimas de uma exploração imoral[",] desabafa, por sua vez, a tradutora Aurora Bernardini..." (Folha de São Paulo, September 8, 1984, p. 31.) 
Portuguese, unlike English, tolerates more variation in marking the shift from narrative to direct speech and introduces an additional mark, the dialog dash, the so called "Travessão" in Portuguese. The change of speaker is signaled by a new paragraph and the opening dialog dash. In (8), while direct speech comes inside quotes and is separated by a comma from the rest of the text in the English TT, in the Portuguese ST only a comma separates direct speech from the rest of the narration.

(8) [-] Continuo a dizer que o menino esta magro[,] disse a mãe resistindo aos solavancos do carro. (p. 110)

"I still think the child is too thin[,"] her mother said, resisting the bumps of the taxi. (p. 115)

\section{TEXTUAL PAIR: Literary}

The Portuguese dialog dash is a language-specific aspect of punctuation which needs to be invariably adjusted in English target texts. But adjustments are also required in translating from English into Portuguese. Because Portuguese admits and takes full advantage of both forms of quotations, translators walk a fine line in deciding on the appropriate level of punctuation when working with Portuguese target texts. Portuguese target texts which fail to take the dialog dash into account have drawn criticism from professional translators (Rónai 1981: 61 and Silveira 1956: 151) in Brazil.

\section{Separating}

Separating a series of three or more elements of the type $A, B$, and $C$ with commas is frequently done in two ways. The first arrangement is to place a comma in between $B$ and $\mathrm{C}$ as seen above. The second arrangement is to leave the two last items of the series unpunctuated, yielding $A, B$ and $C$ type of format. The former style is more representative of some English varieties (again, BE takes the oppsite approach here), whereas Portuguese by and large favors the pattern $A, B$ and $C$ without inserting a comma to separate the next to the last item in the series from the conjunction.

(9) Three different theories were suggested and a series of papers by Ando, Brumberg[,] and Modigliani beginning in the early 1950 's... (p. 186)

Très diferentes teorias foram sugeridas $e$ uma série de artigos iniciadas no começo da década dos 50 por Ando, Brumberg[ ] e Modigliani. (p. 182)

TEXTUAL PAIR: Scientific

The Portuguese TT in (9) is frequently the norm rather than the exception in representating punctuation in a series. Most Brazilian grammar books in fact endorse the pattern $A, B$ and $C$ in listing items in a series. In addition, Portuguese frequently tolerates the omission of the conjunction in listing a series of three or more elements of the type $A$, $B, C+V P$, while omitting the conjunction is a less frequent punctuation pattern in English, in Portuguese its omission may be nay times stylistically desirable.

Stylistically, the use of punctuation to signal verb omission is an acceptable usage in Portuguese. When punctuation takes over the function of a verb, the result is what we read in (10) and (11):

(10) Chamo-me Inácio; ele [,] Benedito. (Cunha, 1980: 579)

(11) Eu entro com o material, e você [,] com o trabalho. (Melo, 1966: 17)

The comma in (10) and (11) takes the function of the verb in the second clause, thus stylistically avoiding the reappearance of the same verb in the following clause. Otherwise, (11) would result in "Eu entro com o material, e você entra com o trablaho." 
What we have in (10) and (11) is a pattern of verb substitution which is clearly language specific. If transposed to English, the output would result in an ungrammatical form. Descriptively, this however does not mean that any deverbalization of punctuation in English invariably results in anomalous outputs. Recent studies indicate that deverbalization of punctuation in English is not only possible but it is also increasingly occurring in print. Little (1984b) reports specifically on the use of the colon as a verb in sentences of the type represented by (12):

(12) The result[:] less need for markdowns to clear out unsold inventory. (Newsweek, January 4, 1988: 34)

In analyzing the use of the colon in her corpus, Little estimates that $10 \%$ to $15 \%$ of colons found were used as a verbal replacement, which indicates that we are perhaps witnessing the dawn of a novel usage of punctuation in the language. Although the colon has so far been used mostly to replace the copula in (12), the pattern we see in (12) is the first approximation to the deverbalization of punctuation in English.

\section{Overusing}

One of the causes which contributes to the increase in the number of punctuation marks per sentence is the use of double punctuation - the simultaneous use of two or more marks. Writers frequently employ [!! ?! - , !, ?,] for different reasons, one of which is to convey an emotional or emphatic appeal to the reader. It is perhaps not surprising that we find the use of double punctuation in the corpus mostly in the literary textual pair.

(13) - Não esqueci de nada [...] recomeçou a mãe, quando uma freada súbita do carro lançou-as malas. Ah! Ah[!,] exclamou a mäe como a um desastre irremediável (p. 111)
"I haven't forgotten anything[...] began her mother again, when a sudden slamming of brakes threw them against each other and sent the suitcases toppling. "Oh! oh!" the older woman exclaimed, as if overtaken by some irremediable dis aster. (p. 116)

TEXTUAL PAIR: Literary

Editorially, the use of double punctuation in Portuguese is an acceptable practice. Double punctuation in English, on the other hand, is strongly discouraged and stigmatized by all manuals of styles and seldom used in practice. "Question marks are never combined with other question marks, exclamation points, periods, or commas," categorically states The Little, Brown Handbook (1983: 298). In translations, duble punctuation is invariably deleted in moving from Portuguese into English as seen in (13). Placed in a broader context, the unacceptability of double punctuation in english makes it consistent with the simplicity and ecnonomy trend towards light punctuation George Summey noticed half a century ago.

\section{Conclusion}

The main purpose of this paper has been to compare the frequency with which punctuation is used in English and Portuguese. Results of a meticulous punctuation count demonstrted that regardless of the genre of textual pairs, Portuguese tends to accept a higher ratio of punctuation marks per sentence than English, tolerating more rhetorical pauses, longer and more complex sentences, and the occasional use of double punctuation. While this research was investigative in nature, its results are capable of having a direct impact on future translation models and on the training of Portuguese and 
English translators. Evidence suggests that adjusting punctuation to conform to target language practices contributes to reducing the element of foreignness in translation, particularly in translations which strive for a level of dynamic equivalence first proposed by Nida (1964: 159). "A translation of dynamic equivalence aims at complete nauainess of expression and tries to relate the receptor to modes of behavior relevant in his own culture," maintains Nida. In striving for complete naturainess in the target language, evidence strongly suggests that translated texts will look and read less like translated texts when appropriate use of punctuation in the target language is observed.

Further question arising from this study still need to be answered. First, although significant differences in the use of punctuation in Portuguese and English were revealed in the study, no attempt was made to explore punctuation as an indicator of translation quality assessment. Further research should be done to determine if punctuation can indeed be used to quantify translation quality in future translation assessment models. Second, since all target texts used in the study were collected from published materials, it was not possible to observe to what extent punctuation was an intrinsic part of the translation process. In other words, how much adjustment punctuation undergoes from the beginning to the final stages of the translation process still remains undetermined. These questions clearly warrant more attention in future studies.

In summary, if translation is indeed one of the most complex activities in the cosmos, as it is often reported in the literature, we are now in a position to begin to recognize the role punctuation plays in the translation process.

\section{NOTE}

1. For the sake of economy, I will use simply Portuguese and English henceforth to refer to Brazilian Portuguese and American English respectively.

\section{TEXTUAL PAIRS CITED IN ORDER OF APPEAREANCE}

Business Textual Pair

ST: Colin, Oswaldo Roberto, Presidente, Banco do Brasil S.A., Mensagem aos Acionistas, Relatório Anual, 1979.

TT: Colin, Oswaldo Roberto, President, Banco do Brasil S.A., Message to the Stockholders, 1979 Annual Report.

Journalistic Textual Pair

ST: Wills, George F. (1983): "Our Fascination with Hitler," Newsweek, May 9, p. 92.

TT: Wills, George F. (1983): "Para Compreender Hitler," Veja, May 11, p. 138.

Literary Textual Pair

ST: Lispector, Clarice (1978): "Laços de Familia," Laços de Família, Rio de Janeiro, Livraria José Olympio Editoral, 10th ed., pp. 119-113.

TT: Lispector, Clarice: "Family Ties," Family Ties, Translated by Giovanni Pontiero, Austin, University of Texas Press. pp. 114-118.

Scientific Textual Pair

ST: Branson, William H. and James M. Litvack (1976): Macroeconomics, New York, Harper \& Row.

TT: Branson, William H. and James M. Litvack: Macroeconomia, Translated by Prof. Silvia Maria Schor, Dept. of Economics of the Faculdade de Economia e Administração de São Paulo, São Paulo, Editora Haper \& Row do Brasil Ltda.

\section{BIBLIOGRAPHY}

CUNHA, Celso Ferreira da (1980): Gramática da Lingua Portuguesa, 7th ed. Rio de Janeiro, Fename. FOWLER, H. W. and F. G. FOWLER (1931): The King's English, 3rd ed. London, Oxford University Press.

The Little, Brown Handbook (1983): H. Ramsey Fowler with the editors of Little, Brown, Boston, Little, Brown \& Company.

LITTLE, Greta D. (1984a): "Punctuation," Research in Composition and Rhetoric, Edited by Michael G. Moran and Ronald F. Lunsford. 
LITTLE, Greta D. (1984b): "The Colon as a Verb," a paper presented at the Kentucky Foreign Language Conference at Lexington, Kentucky.

MATTOSO CÂMARA, Jr., Joaquim (1977): Manual de Expressão Oral e Escrita, 4th ed. Petrópolis, Editora Vozes, Ltda.

MELO, Hélio (1966): Tudo sobre Pontuação, 2nd ed. Fortaleza, Escola Industrial Federal de Ceara

NICHOLS, Ann Eljenholm (1962): "Punctuation Problems for Speakers of Germanic Languages," Lang L, 12, pp. 195-204.

NIDA, Eugene A. (1964): Toward a Science of Translating, Brill, Leiden.

NIDA, Eugene A., Charles TABER (1969): The Theory and Practice of Translation, Leiden, Brill.

OLÍVIA, Madre (1982): Uso da Virgula, 4th ed. Petropolis, Vozes.

PASSOS, Alexandre da Silva (1959): A Arte de Pontuar, Rio de Janeiro, Irmãos Pongetti Editores, 5th ed.

RÓNAI, Paulo (1981): A Traduçäo Vivida, 2nd ed. rev. \& enlarged, Rio de Janeiro, Nova Fronteira.

SILVEIRA, Brenno (1954): A Arte de Traduzir, São Paulo, Editora Melhoramento.

SPILKA, Irène (1983): "Traduction et ponctuation," Canadian Journal of Linguistics, 28, pp. 55-70.

SPILKA, Irène (1985): Punctuation in Translation, Paper presented at the American Translators Association Conference Miami, October, pp. 16-20.

SUMMEY, George (1919): Modern Punctuation: Its Utilities and Conventions, New York, Oxford University Press.

SUMMEY, George (1949): American Punctuation, New York, Ronald. 